\title{
溶融 $\mathrm{Al}$ への $\mathrm{Ni}$ 線浸漬実験に基づく燃焼合成時の $\mathrm{Ni}_{3} \mathrm{Al}$ 金属間化合物の反応速度パラメー夕の推定 ${ }^{\dagger}$
}

\author{
日比野敦 \\ 電気通信大学電気通信学部機械制御工学科
}

J. Japan Inst. Metals, Vol. 57, No. 7 (1993), pp. 767-773

\author{
Estimation of Kinetic Parameters for Combustion Synthesis of $\mathrm{Ni}_{3} \mathrm{Al}$ \\ Intermetallic Compound by Dipping Ni Wire into Al Melt
}

\author{
Atsushi Hibino
}

\author{
Department of Mechanical and Control Engineering, University of Electro-Communications, Chofu, Tokyo
}

\begin{abstract}
The formation rate of Ni-Al intermetallic compounds was measured by dipping Ni wire into $\mathrm{Al}$ melt in the temperature range between $973 \mathrm{~K}$ and $1373 \mathrm{~K}$, in order to determine the kinetic parameters of combustion synthesis of $\mathrm{Ni}_{3} \mathrm{Al}$. The $\mathrm{Ni}$ wire and $\mathrm{Al}$ powders were put into an alumina crucible and vacuum-sealed in a quartz tube. The tube was kept in an electric furnace to cause the compound formation reaction. The microstructure observation and EDX analysis of the dipped $\mathrm{Ni}$ wire were performed. It was found that the compound formation reaction occurred at the interface between the molten $\mathrm{Al}$ and the $\mathrm{Ni}$ wire, and the cylindrical $\mathrm{Ni}_{2} \mathrm{Al}_{3}$ layer was formed in the wire. The thickness of the formed layer depended on the holding time and the dipping temperature. The reaction process had been closely similar to the combustion synthesis process of $\mathrm{Ni}_{3} \mathrm{Al}$ intermetallic compound. Therefore, the kinetic parameters could be determined by the dipping experiment. The experimental data have been analyzed with a cylindrical model which took into account the diffusion process of $\mathrm{Al}$ in the compound layer and chemical reaction on the interface between $\mathrm{Ni}_{2} \mathrm{Al}_{3}$ and $\mathrm{Ni}$. The diffusion coefficient, $D_{\mathrm{Al}}$, and the reaction rate constant, $k_{c}$, were estimated as follows.
\end{abstract}

$$
\begin{gathered}
D_{\mathrm{A} 1} / \mathrm{mol} \cdot \mathrm{m}^{-1} \cdot \mathrm{s}^{-1}=1.20 \times 10^{-3} \cdot \exp (-89000 / R T) \\
k_{\mathrm{c}} / \mathrm{mol} \cdot \mathrm{m}^{-2} \cdot \mathrm{s}^{-1}=1.35 \times 10^{4} \cdot \exp (-120000 / R T)
\end{gathered}
$$

The calculated curves by using present the kinetic parameters were in satisfactory agreement with the experimental values.

(Received December 28, 1992)

Keywords: $\mathrm{Ni}_{3} \mathrm{Al}, \mathrm{Ni}_{2} \mathrm{Al}_{3}$, intermetallic compound, kinetics, reaction mechanism, combustion synthesis, reaction sintering

\section{I，緒言}

近年, TiAl, $\mathrm{Ni}_{3} \mathrm{Al}$ に代表される金属間化合物の合成法とし て燃焼合成法(1)-(5)が注目されて㧍り，そのプロセス制御を目 指して，合成過程や反応機構に関する研究が精力的に進められ ている(6)-(18). しかしながら，燃焼合成では粉末の反応と反応 熱, 扣よび相変化等の問題が複雑に絡み, しかもこ机らの現象 が極めて高速に進行することからその詳細は未だ明らかとは されていない。

このような背景から，著者は燃焼合成の反応機構解析を目的 として, $\mathrm{Ni}_{3} \mathrm{Al}$ の然焼合成過程についての調査を行い, その反 応モデルを作成した (19)。このモデルに基つけば，燃焼合成の 反応過程や反応機構は、シミュレーションによって推㵋できる と考光られる。このよらな解析のためには，熱力学データ扎よ び反応速度定数等の物珄值がモデルのパラメータとして必要と

† 1992年 4 月日本金属学会春期大会に括いて一部発表
なる、このうら熱力学データについてはこれまでに多くの報告 がなされ，信頼性のある值が文献(20)(21) 亿集録されるようにな ってきた、しかしながら，反応速度定数あるいは执散係数とい った反応速度に関寸る報告例は穵しく，Ni-Al系についての值 は注とえど知られていないのが現状である。をこで，本研究で は, $\mathrm{Ni}_{3} \mathrm{Al}$ の然焼合成の基礎として固体 $\mathrm{Ni}$-溶融 $\mathrm{Al}$ 系に扣ける 化合物の成長速度を調べ，この結果㳻づき本基の反応速度パ ラメータを推定することを試みた。

\section{II. 実 験 方 法}

Fig. 1 に，本研究の浸漬実験の概略を示す，浸漬実験は Ni ワイヤー特よび $\mathrm{Al}$ 粉末試料を石英アンプルK封入し，このア ソプルを電気炬内で加熱保持する力法で行った。この際に試料 の䨌囲気は真空雾囲気とした．試料の酸化を防ぐ観点からは雾 用気は，不活性ガス下，真空下とも大きな差異は無い。乙か し，ガスの膨張㶤起因するNiワイヤーとAl の接触不良およ び $\mathrm{Al}$ 粉末試料の飛散等を考慮すると真空の方が利点が多いと 

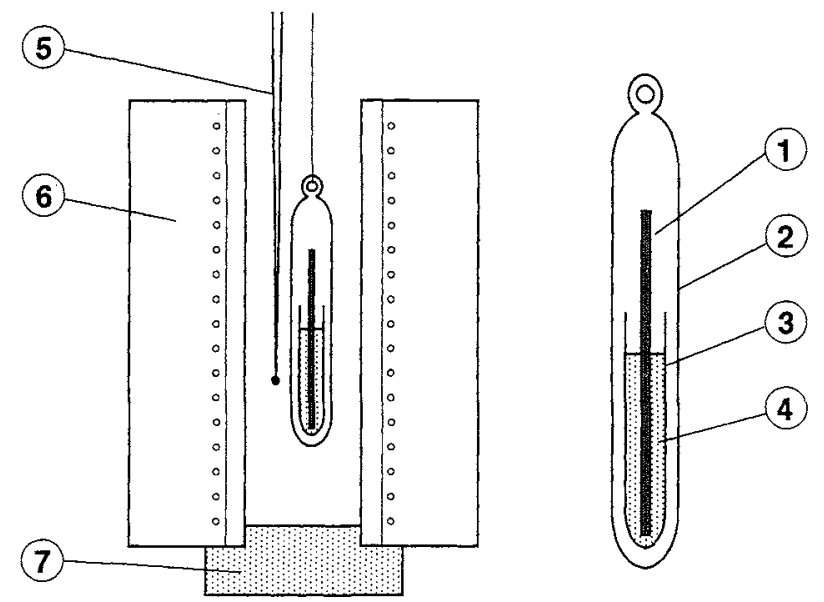

Fig. 1 Experimental apparatus for determination of diffusion coefficient, $D_{\mathrm{Al}}$, and reaction rate constant, $k_{\mathrm{c}}$. (1) $\mathrm{Ni}$ wire $(\phi 1 \mathrm{~mm}),(2)$ Quartz capsule (Evacuated), (3) Alumina crucible, (4) Al melt (Ni added), (5) Thermocouple,

(6) Electric furnace, (7) Insulator.

考光られる。そこで，燃焼合成の場合 ${ }^{(19)}$ と条件を合わ子る意 味子含め, 雲囲気恃真空下を選択した。

供試体は, 直径 $1 \mathrm{~mm}$ の Ni ワイヤー(ニラコ社製) と, 平均 粒径 $3 \mu \mathrm{m}$ のアトマイズ $\mathrm{Al}$ 粉末(東洋アルミニウム社製) 括よ
び平均精径 $3 \mu \mathrm{m}$ のカーボニル Ni 粉末（日興プロダクッ社製） である。実験は，Ni ワイヤーをアルミナるつぱ(ニッカト一社 製)に入れ，るつ济とワイヤーの腺間に Ni 飽和組成をるつ Ni/ $\mathrm{Al}$ 混合粉末を充填した。このるつぼを透明石英間に入れた後, $1.33 \times 10^{-4} \mathrm{~Pa}\left(10^{-6}\right.$ Torr $)$ 以上の真空度で封入し，このアンプ ルを炉内で $973 \mathrm{~K}, 1173 \mathrm{~K}$ 和よび $1373 \mathrm{~K}$ の盜度に保持をし た. 所定の時間(0〜216 ks)が経過したならばアンプルを炉か ら取り出し，試料を急冷した，得られた試料は，その断面形状 を光学顕钽鏡で観察し，化合物層の厚さ蛙よび未反応の Ni 径 を測定した。 また，一部の試料については化合物層の相を同定 するため，EDXによる組成分析を行った，保持温度切よび保 持時間を変えた条件下で浸漬実験を繰り返し、ワイヤー内部の 化合物層の形成速度を測定した。

\section{III、結果および考察}

Fig. 2 は， $\mathrm{Ni}_{3} \mathrm{Al}$ の燃焼合成過程を明らかとするために，原 子比で $\mathrm{Ni}: \mathrm{Al}=3: 1$ の混合王粉体を燃烇合成させ，これを反 応途中で急冷した試料の組織である(19)。この図の中で，(a)は 反応前の王粉体の組織写真であり，(b)は反応開始直後に急冷 した試料の組織写真，(c)双応終了直前に急冷した試料の組 織，(d)は燃烷合成終了後の試料の組織である。また，各写真 の中で白い粒子がNi粒子であり，灰色の粒子は $\mathrm{Al}$ 粒子であ

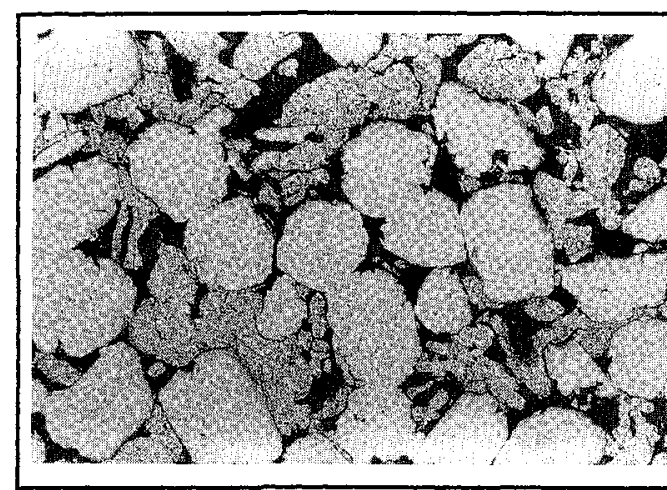

(a) Green Compact.

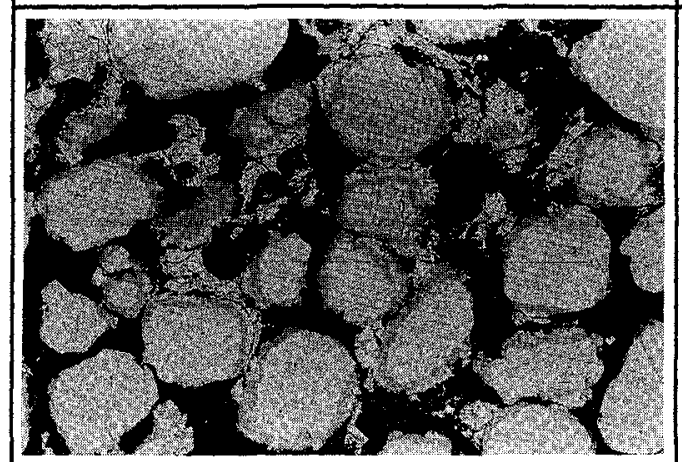

(c) During Combusion Synthesis.

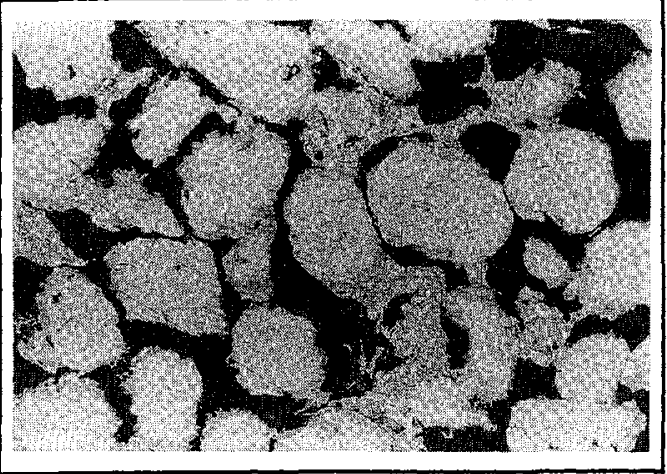

(b) During Combusion Synthesis.

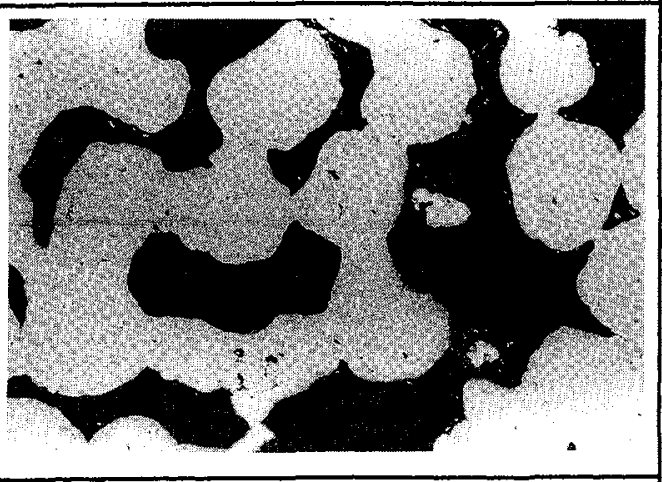

(d) Synthesized Product.

Fig. 2 Micrographs of Ni/Al compacts during the combustion synthesis. (a) Green compact. (b) Quenched at the beginning of the combustion synthesis process. (c) Quenched at the end of the combustion synthesis process. (d) Synthesized product. 
る、この図にみられるように，本系の燃焼合成では厈粉体内部 $\mathrm{Al}$ 粒子が融解し(Fig. 2(b))，この $\mathrm{Al}$ 融夜と $\mathrm{Ni}$ 粒子との反 応により金属間化合物が形成されている(Fig. 2(c))。本研究 では，このような反応の模擬実験として溶融 $\mathrm{Al}$ 中に Ni ワイ ヤーを浸漬する実験を試みた。

Fig. 3 K，その浸漬後のNi ワイヤー断面の一例を示す。こ

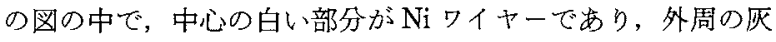
色の領域がA1融液の部分である。図にみられるように，浸漬 後の Ni ワイヤーには同心円状の金属間化合物層が形成され， 浸漬実験でる燃烍合成と同じく Alと Niの反応を起こさせる ことができた。ここで浸清条件による化合物の生成量の違い炕 着目すると，浸漬時間を長くした場合では時間の增加につれて 化合物の生成量は増加した。 未た，浸漬温度を変えた場合で む，温度を973〜1373 K と高くするにつれて生成量が増える ことがわかった。

Fig. 4 に浸漬後の Ni ワイヤーの拡大写真を，またTable 1 に, Fig. 4 中の A $\sim \mathrm{E}$ の位置に括ける EDX 分析の結果を示 す.この図の中で(a)は，973 K で $3.6 \mathrm{ks}$ (1 時間)浸漬した試 料の分析結果であり，(b)は $1173 \mathrm{~K}, 3.6 \mathrm{ks}$ の試料，(c) は $1373 \mathrm{~K}, 3.6 \mathrm{ks}$ 浸漬した試料の分析結果である。これらの分析 結果から，本浸漬実験で生成した化合物層は，原子分率でおよ そ $X_{\mathrm{Ni}} \fallingdotseq 0.36, X_{\mathrm{A} 1} \fallingdotseq 0.64$ 組成の化合物であることがわかる。 この組成を $\mathrm{Ni}-\mathrm{Al}$ 系状態図(22) と照合した結果，これらは $\mathrm{Ni}_{2} \mathrm{Al}_{3}$ であることが明らかになった。

Fig. 5 は，然焼合成途中で急冷した試料(Fig. 2(c))の粒子 を拡大した写真である ${ }^{(19)}$ 。この図から明らかなよらに，燃焼 合成途中の試料では，化合物各粒子内に同心円状に形成されて

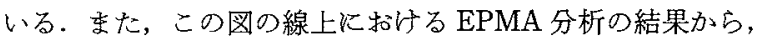
生成した化合物は $\mathrm{Ni}_{2} \mathrm{Al}_{3}$ であることがわかる，以上の結果か らすると，Ni-Al系では浸漬実験，然焼合成ともに類似な組織

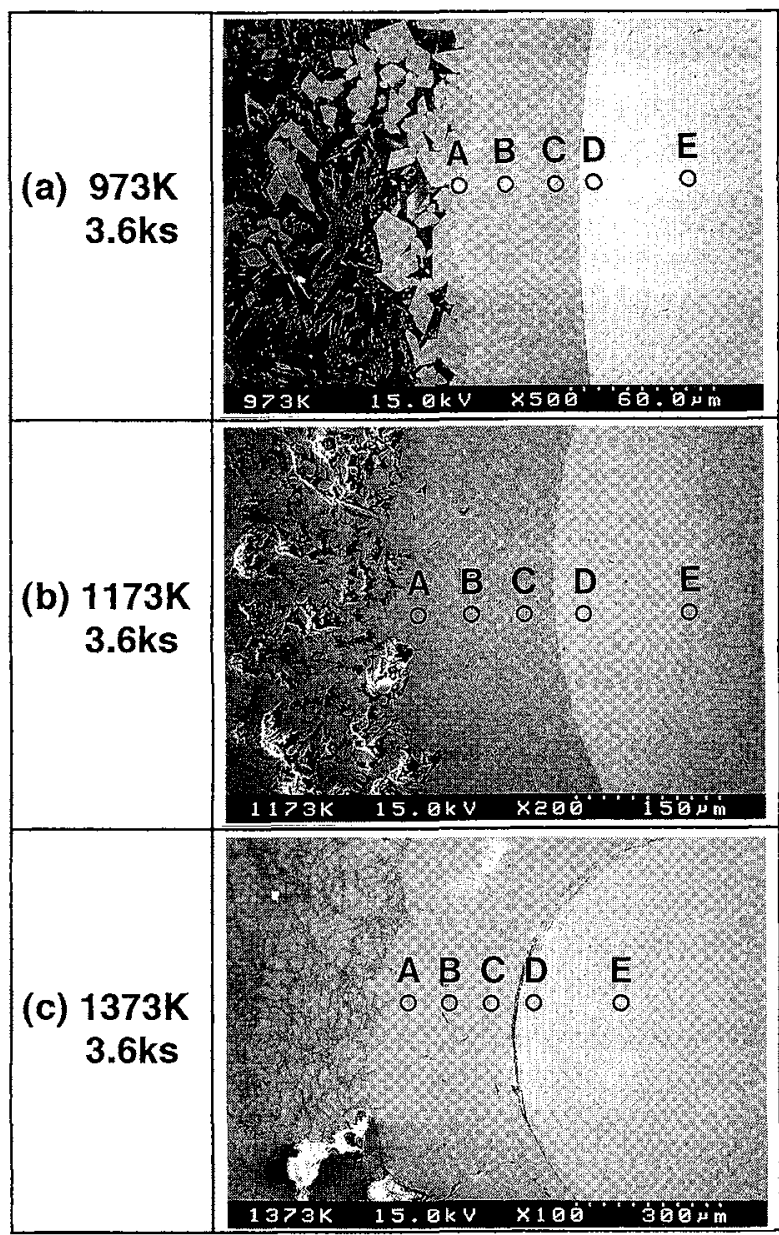

Fig. 4 Micrographs of the intermetallic compound layer. EDX analysis was performed at the marked points.

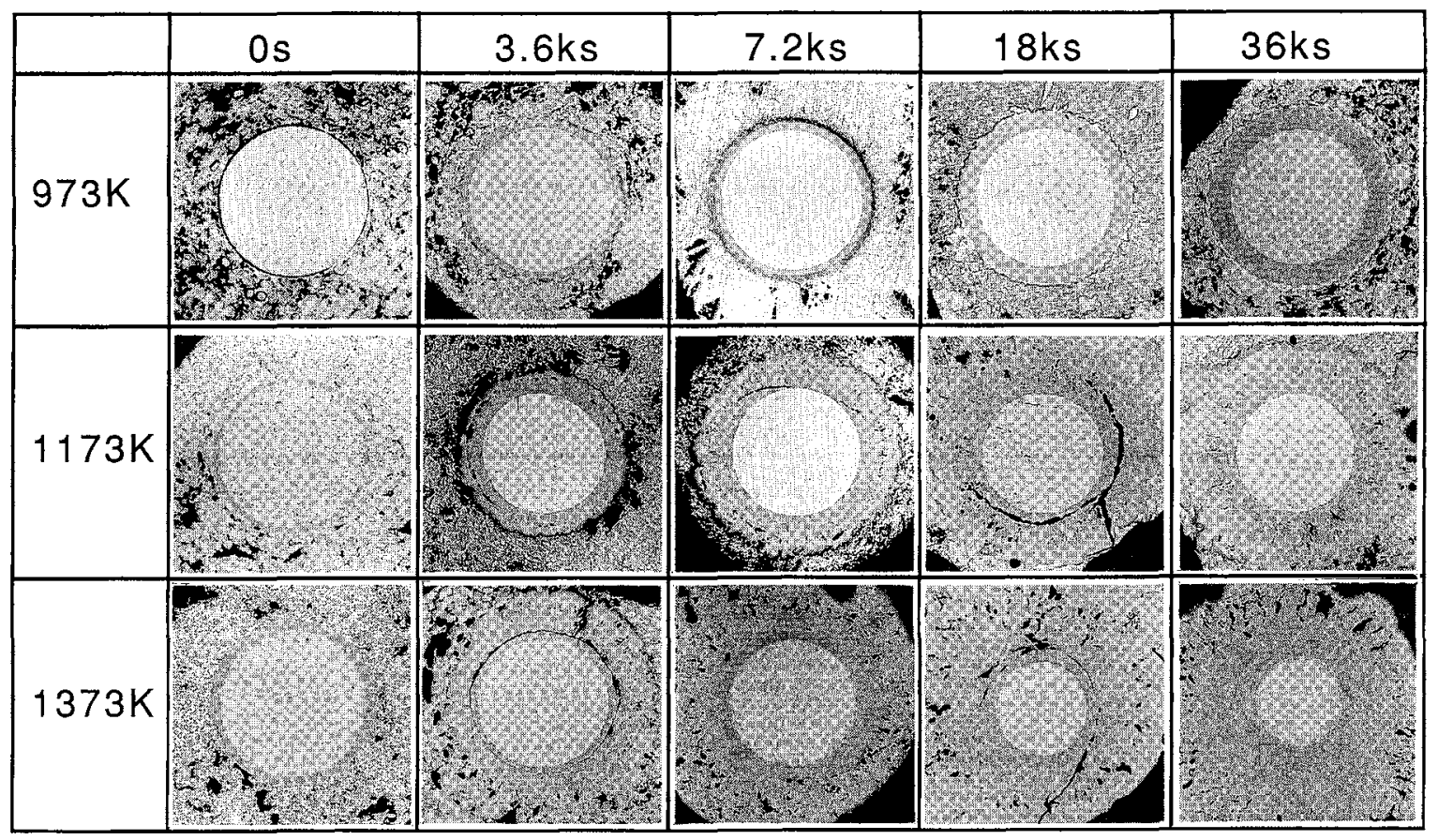

Fig. 3 The cross sections of the dipped Ni wires. 
Table 1 Result of EDX analysis of the depped Ni wire.

\begin{tabular}{c|c|c|c|c|c}
\hline Sample & Point & mass\%Ni & \multirow{2}{*}{ mass\%Al } & \multicolumn{2}{|c}{ Atomic fraction } \\
& & & & $X_{\mathrm{Ni}}$ & \multicolumn{1}{|c}{$X_{\mathrm{Al}}$} \\
\hline & $\mathrm{A}$ & 52.5 & 47.5 & 0.337 & 0.663 \\
& $\mathrm{~B}$ & 54.9 & 45.1 & 0.359 & 0.641 \\
(a) $973 \mathrm{~K}$ & $\mathrm{C}$ & 56.3 & 43.7 & 0.372 & 0.628 \\
$3.6 \mathrm{ks}$ & $\mathrm{D}$ & 100.0 & 0 & 1.000 & 0 \\
& $\mathrm{E}$ & 100.0 & 0 & 1.000 & 0 \\
\hline & $\mathrm{A}$ & 54.3 & 45.7 & 0.353 & 0.647 \\
& $\mathrm{~B}$ & 52.7 & 47.3 & 0.339 & 0.661 \\
(b) $1173 \mathrm{~K}$ & $\mathrm{C}$ & 56.1 & 43.9 & 0.370 & 0.630 \\
$3.6 \mathrm{ks}$ & $\mathrm{D}$ & 100.0 & 0 & 1.000 & 0 \\
& $\mathrm{E}$ & 100.0 & 0 & 1.000 & 0 \\
\hline & $\mathrm{A}$ & 56.1 & 43.9 & 0.370 & 0.630 \\
& $\mathrm{~B}$ & 54.1 & 45.9 & 0.351 & 0.649 \\
(c) $1373 \mathrm{~K}$ & $\mathrm{C}$ & 57.7 & 42.3 & 0.386 & 0.614 \\
$3.6 \mathrm{ks}$ & $\mathrm{D}$ & 100.0 & 0 & 1.000 & 0 \\
& $\mathrm{E}$ & 100.0 & 0 & 1.000 & 0 \\
\hline
\end{tabular}
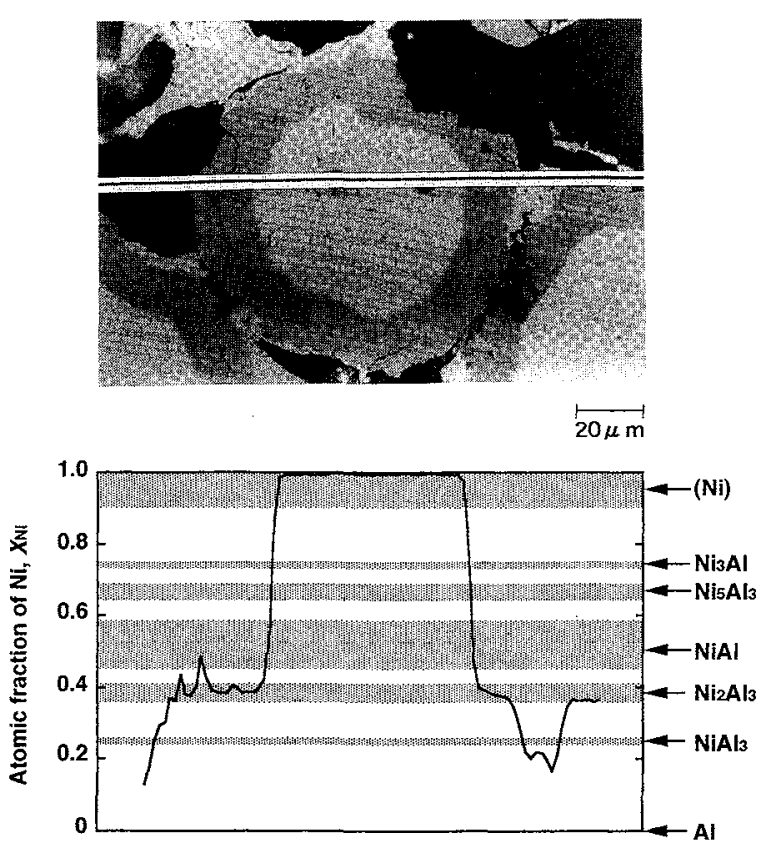

Fig. 5 Result of EPMA analysis of the quenced $\mathrm{Ni} / \mathrm{Al}$ powder compact shown in Fig. 2(c).

を形成し，をた同じ化合物を生成することになるそとてでこ の浸漬実験の結果に基づいて，燃焼合成の反応速度パラメータ を決定した. 万法は，漫漬時の反応モデルを作製し，このモデ ルを用いて実験結果を整理する方法で行った。

Fig. 6K，反応モデルの概略を示す。ここでは試料の形状 ならびに Fig. 4 を考慮して外側が $\mathrm{Al}$ 融夜 ( $\mathrm{Ni}$ 飽和), 中間層

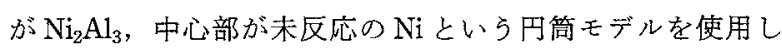
た.な执，このモデルに㧊ける化合物の生成経路は以下の 2 段階を仮定した。すなわら，

(a) 外周の $\mathrm{Al}$ は， $\mathrm{Ni}_{2} \mathrm{Al}_{3}$ 層の内部を拡散して $\mathrm{Ni}_{2} \mathrm{Al}_{3} / \mathrm{Ni}$ 界 面に移動する。

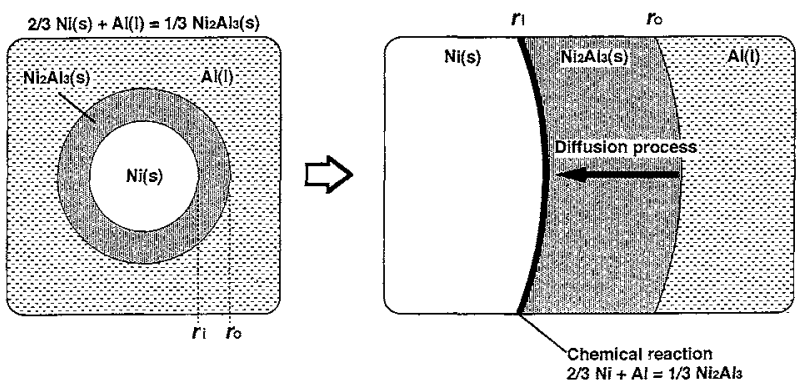

Fig. 6 Cylindrical model for the determination of diffusion coefficient, $D_{\mathrm{Al}}$, and reaction rate constant, $k_{\mathrm{c}}$.

(b) $\mathrm{Ni}_{2} \mathrm{Al}_{3} / \mathrm{Ni}$ 界面に到達した $\mathrm{Al}$ は, $\mathrm{Ni}$ と反応し $\mathrm{Ni}_{2} \mathrm{Al}_{3}$ 層 を形成する。

との反応経路を仮定した。

実際の反応では, 和そらく複数の反应が併発するい嬘次的 に進行し, 複雑な経路によって化合物は生成すると推察され る. 李た, 化合物の生成経路は, 浸漬温度や浸漬時間飞上り変 化する可能性も考えられる. しかし現時点ではその詳細が不明 であるため，ここでは仮定として上記の 2 段階を考えた。 た，浸漬実験の場合でも化合物の生成に伴って反応熱が発生 し，試料温度は浸漬途中で変化することが子想される。しか $し$ ，本浸漬実験の場合には，然焼合成と此較して単位体積あた りの Ni の表面積が小さく, 化合物の生成は比較的遅い速度で 准行する。また，化合物生成伴って発生する熱量る，るつぼ 内の物質の全熱容量と比較して無視しらる量であると考觉られ る. そこで, 本研究では反応熱の問題を無視し，一定温度で反 応が進行するるのと考党て以下の反応速度式を導出した。

(a)の段階の $\mathrm{Ni}_{2} \mathrm{Al}_{3}$ 層に敊ける $\mathrm{Al}$ の拡散速度 $\dot{n}_{\mathrm{d}}\left[\mathrm{mol} \cdot \mathrm{s}^{-1}\right]$ 恃,

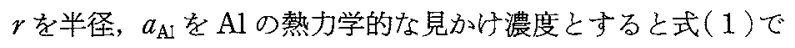
表される(23).

$$
\dot{n}_{\mathrm{d}}=2 \pi r l D_{\mathrm{A} 1}\left(\frac{\mathrm{d} a_{\mathrm{AI}}}{\mathrm{d} r}\right) \quad\left[\mathrm{mol} \cdot \mathrm{s}^{-1}\right]
$$

ここで，lは浸漬したNiワイヤー長である.

Fig. 6のモデルに执いて定常的な拡散が执こる場合，すなわ ち, $\mathrm{Al} / \mathrm{Ni}_{2} \mathrm{Al}_{3}$ 界面から $\mathrm{Ni}_{2} \mathrm{Al}_{3}$ 層に取り込まれる $\mathrm{Al}$ のル数 と, $\mathrm{Ni}_{2} \mathrm{Al}_{3} / \mathrm{Ni}$ 界面から放出されるモ几数が等しい場合には， $\dot{n}_{\mathrm{d}}$ はr $r_{\mathrm{i}} \sim r_{\mathrm{o}}$ 間で一定であると考光られる.そこで, 式(1)を $r$ で積分すると式 $(2)$ が得られる.

$$
\dot{n}_{\mathrm{d}}=2 \pi l D_{\mathrm{A}:} \frac{a_{\mathrm{AI}, 0}-a_{\mathrm{Al}, \mathrm{i}}}{\ln \left(r_{0} / r_{\mathrm{i}}\right)} \quad\left[\mathrm{mol} \cdot \mathrm{s}^{-1}\right]
$$

ここで $r_{\mathrm{i}}$ は, $\mathrm{Ni}$ の半径, $r_{0}$ は $\mathrm{Al}$ 融液と $\mathrm{Ni}_{2} \mathrm{Al}_{3}$ が接触する界 面の半径であり， $D_{\mathrm{A} 1}$ は $a_{\mathrm{Al}}$ 亿対する $\mathrm{Ni}_{2} \mathrm{Al}_{3}$ 層内の $\mathrm{Al}$ の拡散 保数である。 $a_{\mathrm{Al}, \mathrm{o}}$ は, Ni ワイヤー周囲の溶融 $\mathrm{Al}$ の熱力学的 な見かけ濃度であり， $a_{\mathrm{Al}, \mathrm{i}}$ は, $\mathrm{Ni}_{2} \mathrm{Al}_{3} / \mathrm{Ni}$ 界面に敊ける $\mathrm{Al} の$ 熱力学的な見かけ濃度である。

一方，(b)の化合物が生成する過程は， $\mathrm{Ni}_{2} \mathrm{Al}_{3} / \mathrm{Ni}$ 界面に打け

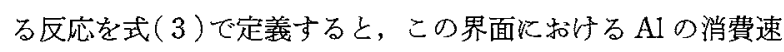
度的は式 (4)で与えられる(23)。 


$$
\begin{aligned}
& (2 / 3) \mathrm{Ni}+\mathrm{Al} \underset{k_{\mathrm{b}}, v_{\mathrm{b}}}{\stackrel{k_{\mathrm{c}}, v_{\mathrm{c}}}{\rightleftharpoons}}(1 / 3) \mathrm{Ni}_{2} \mathrm{Al}_{3} \quad K=\frac{k_{\mathrm{c}}}{k_{\mathrm{b}}} \\
& \dot{n}_{\mathrm{c}}=2 \pi r_{\mathrm{i}} l\left(k_{\mathrm{c}} \cdot a_{\mathrm{Ni}, \mathrm{i}}^{2 / 3} \cdot a_{\mathrm{Al}, \mathrm{i}}-k_{\mathrm{b}} \cdot a_{\mathrm{Ni}_{2} \mathrm{Al} \mathrm{I}_{\mathrm{i}} \mathrm{i}}^{1 / 3}\right) \\
& =2 \pi r_{\mathrm{i}} l\left(k_{\mathrm{c}} \cdot a_{\mathrm{Al}, \mathrm{i}}-k_{\mathrm{b}}\right) \quad\left[\mathrm{mol} \cdot \mathrm{s}^{-1}\right]
\end{aligned}
$$

ここで $a_{\mathrm{Al}, \mathrm{i}}, a_{\mathrm{Ni}, \mathrm{i}}, a_{\mathrm{Ni}_{2} \mathrm{Al} 3, \mathrm{i}}$ は, $\mathrm{Ni}_{2} \mathrm{Al}_{3} / \mathrm{Ni}$ 界面见特沙る $\mathrm{Al}, \mathrm{Ni}$, $\mathrm{Ni}_{2} \mathrm{Al}_{3}$ の熱力学的なみかけ濃度であり, $K$ は平衡定数, $k_{c}, k_{5}$ は反応速度定数である。

Fig. 6 のモデル顿いてNiと $\mathrm{Al}$ の反応が定常的に進行す る場合には，拡散によって $\mathrm{Ni}_{2} \mathrm{Al}_{3} / \mathrm{Ni}$ 界面に供給される $\mathrm{Al} の$ モル数と, $\mathrm{Ni}_{2} \mathrm{Al}_{3}$ の反応生成伴って消費される $\mathrm{Al}$ のニ数 は等しいと考兄られる。また，Ni ワイヤー全体として消費さ れる $\mathrm{Al}$ のモル数も等しいと考えられる。そこで，これらの物 質収支を考光ると式 $(5)$ の関係が成立する。

$$
\dot{n}_{\mathrm{A} 1}=\dot{n}_{\mathrm{d}}=\dot{n}_{\mathrm{c}} \quad\left[\mathrm{mol} \cdot \mathrm{s}^{-1}\right]
$$

ここで， $\dot{n}_{\mathrm{A} 1}$ は, Ni ワイヤー全体の $\mathrm{Al}$ の消費速度である。

式(2)，(3)，(4)を組合世, 式(5)の関俰を用いて各項を整 理すると, 浸漬実験に関する反応速度式は式(6)のよ5に表 される。

$$
\dot{n}_{\mathrm{AL}}=\frac{2 \pi r_{\mathrm{o}} l\left(a_{\mathrm{A}, \mathrm{o}}-1 / K\right)}{r_{\mathrm{o}} \cdot \ln \left(r_{\mathrm{o}} / r_{\mathrm{i}}\right) / D_{\mathrm{Al}}+r_{\mathrm{o}} / r_{\mathrm{i}} k_{\mathrm{c}}}
$$

しかし, この式で求るのは $\mathrm{Al}$ の消費速度 $\dot{n}_{\mathrm{A} 1} と r_{\mathrm{i}}, r_{0}$ の関係 であり，Fig. 3 の結果を整理するためには取扱いが不便であ る. そこで, 転換率 $C_{\mathrm{w}}$ 式 $(7)$ のように定義すると, 以下の 式が導出でさる.

$$
C_{\mathrm{w}}=\frac{r_{\mathrm{s}}^{2}-r_{\mathrm{i}}^{2}}{r_{\mathrm{s}}^{2}}=\frac{\text { 消費された } \mathrm{Ni} の \text { 体積 }}{\text { 浸漬前の Ni } \text { 体積 }}
$$

$r_{\mathrm{i}}$ は, 武 $(7)$ 変形して,

$$
r_{\mathrm{i}}=r_{\mathrm{s}}\left(1-C_{\mathrm{w}}\right)^{1 / 2}
$$

r。は，Nik関する物質收支，式( 3 )，(9)を用いることによ り式(10)，(11)の上引婊せる.

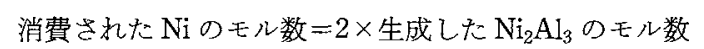

$$
\begin{aligned}
& \pi\left(r_{\mathrm{s}}^{2}-r_{\mathrm{i}}^{2}\right) l \frac{\rho_{\mathrm{Ni}}}{M_{\mathrm{Ni}}}=2 \pi\left(r_{\mathrm{o}}^{2}-r_{\mathrm{i}}^{2}\right) l \frac{\rho_{\mathrm{Ni} 2 \mathrm{Al} 3}}{M_{\mathrm{Ni} 2 \mathrm{Al} 3}} \\
& r_{0}=r_{\mathrm{s}}\left\{\left(\frac{\rho_{\mathrm{Ni}} \cdot M_{\mathrm{Ni} 2 \mathrm{Al}_{3}}}{2 M_{\mathrm{Ni}} \cdot \rho_{\mathrm{Ni2A} 13}}-1\right) C_{\mathrm{w}}+1\right\}^{1 / 2}
\end{aligned}
$$

ここで, $\rho_{\mathrm{Ni}}, \rho_{\mathrm{Ni}_{2} \mathrm{Al} l_{3}}$ は, $\mathrm{Ni}, \mathrm{Ni}_{2} \mathrm{Al}_{3}$ の密度であり, $M_{\mathrm{Ni}}, M_{\mathrm{Ni}_{2} \mathrm{Al}}$ はこれらのモル量である。

また， $\dot{n}_{\mathrm{Al}}$ 飞ついては Alk関する物質収支，式 (3)，(12)を 用いて，式(13)，(14)のように表せる.

消費された $\mathrm{Al}$ のル数 $=3 \times$ 生成した $\mathrm{Ni}_{2} \mathrm{Al}_{3}$ のモル数

$$
\begin{aligned}
& n_{\mathrm{Al}}=3 \pi\left(r_{0}^{2}-r_{\mathrm{i}}^{2}\right) l \frac{\rho_{\mathrm{Ni} 2 \mathrm{Al} 3}}{M_{\mathrm{Ni2Al} 3}} \\
& \dot{n}_{\mathrm{Al}}=\frac{3}{2} \pi r_{\mathrm{s}}^{2} l \frac{\rho_{\mathrm{Ni}}}{M_{\mathrm{Ni}}} \dot{C}_{\mathrm{w}}
\end{aligned}
$$

したがってこれらの関保を用いると, 式(6)は式(15)の上 ら火書き改められる。

$$
\frac{3}{2} \pi r_{\mathrm{s}}^{2} l \frac{\rho_{\mathrm{Ni}}}{M_{\mathrm{Ni}}} \dot{C}_{\mathrm{w}}=\frac{2 \pi r_{\mathrm{s}} \beta^{1 / 2} l\left(a_{\mathrm{Al}, \mathrm{o}}-1 / K\right)}{\frac{\beta^{1 / 2} r_{\mathrm{s}}}{D_{\mathrm{Al}}} \ln \left(\frac{\beta^{1 / 2}}{\alpha^{1 / 2}}\right)+\frac{\beta^{1 / 2}}{\alpha^{1 / 2} k_{\mathrm{c}}}}
$$

ここで, $\alpha, \beta$ は

$$
\begin{aligned}
& \alpha=1-C_{\mathrm{w}} \\
& \beta=\left(\frac{\rho_{\mathrm{Ni}} \cdot M_{\mathrm{Ni}_{2} \mathrm{Al}}}{2 M_{\mathrm{Ni}} \cdot \rho_{\mathrm{Ni} 2 \mathrm{Al}}}-1\right) C_{\mathrm{w}}+1
\end{aligned}
$$

である。この式(15)の雨辺を積分すると、式(16)が得られる。 すなわち，転換率 $C_{\mathrm{w}}$ と時間 $t$ 関係が実験以よって決定され れば，反灾速度定数 $k_{\mathrm{c}}$ と执散俰数 $D_{\mathrm{Al}}$ が決定できることにな る・

$$
\frac{3}{2} r_{\mathrm{s}}^{2} \frac{\rho_{\mathrm{Ni}}}{M_{\mathrm{Ni}}}\left\{\gamma \frac{1}{D_{\mathrm{Al}}}+\delta \frac{1}{k_{\mathrm{c}}}\right\}=2\left(a_{\mathrm{A} 1,0}-1 / K\right) t
$$

ここで

$$
\begin{aligned}
& \gamma=\frac{1}{2}\left[\frac { ( \frac { \rho _ { \mathrm { Ni } } \cdot M _ { \mathrm { Ni } _ { 2 } \mathrm { A } I _ { 3 } } } { 2 M _ { \mathrm { Ni } } \cdot \rho _ { \mathrm { Ni } _ { 2 } \mathrm { A } I _ { 3 } } } - 1 ) C _ { \mathrm { w } } + 1 } { \frac { \rho _ { \mathrm { Ni } } M _ { \mathrm { Ni } 2 \mathrm { A } l _ { 3 } } } { 2 M _ { \mathrm { Ni } } \rho _ { \mathrm { Ni } 2 \mathrm { A } l _ { 3 } } } - 1 } \operatorname { l n } \left\{\left(\frac{\rho_{\mathrm{Ni}} \cdot M_{\mathrm{Ni} 2 \mathrm{~A} l_{3}}}{2 M_{\mathrm{Ni}} \cdot \rho_{\mathrm{Ni} 2 \mathrm{Al}}}-1\right)\right.\right. \\
& \left.\left.\times C_{\mathrm{w}}+1\right\}+\left(1-C_{\mathrm{w}}\right) \ln \left(1-C_{\mathrm{w}}\right)\right]
\end{aligned}
$$

$\delta=\frac{2}{r_{\mathrm{s}}}\left\{1-\left(1-C_{\mathrm{w}}\right)^{1 / 2}\right\}$

である.そこで，この式(16)を用いて Fig. 3 の整理を行った.

Fig. 7 に, Fig. 3 の断面から末反応の Ni 部の径を測り，こ れから転換率 $C_{\mathrm{w}}$ 之時間の関係を求めた結果を示す．図中の実 線については後述するが, 各試料の転換率 $C_{\mathrm{w}}$ は, 各プロット の上らに浸漬時間の増加につれて放物線状に増える傾向を示し た。また，浸漬温度を変えた場合では，温度の高い試料はど転 換率 $C_{\mathrm{w}}$ の值は高い値を示した.

Fig. 8 K，この転換率 $C_{\mathrm{w}}$ と浸漬時間 $t$ を式(16)飞代入し， 抬散係数 $D_{\mathrm{A} 1}$ と反応速度定数 $k_{\mathrm{c}}$ をパラメータフィッティング により求めた結果を示す。な特，式(16)右辺には未知の值と

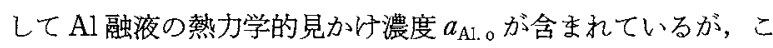
こでは文献(21)(24) 記記載されている，式(17)を用いてその値を 算出した。

$$
R T \cdot \ln \gamma_{\mathrm{Al}}=-21720\left(1-X_{\mathrm{Al}}\right)^{2}
$$

Fig. 8 K見られるように, 求められた反応速度定数 $k_{c}$ と拡散

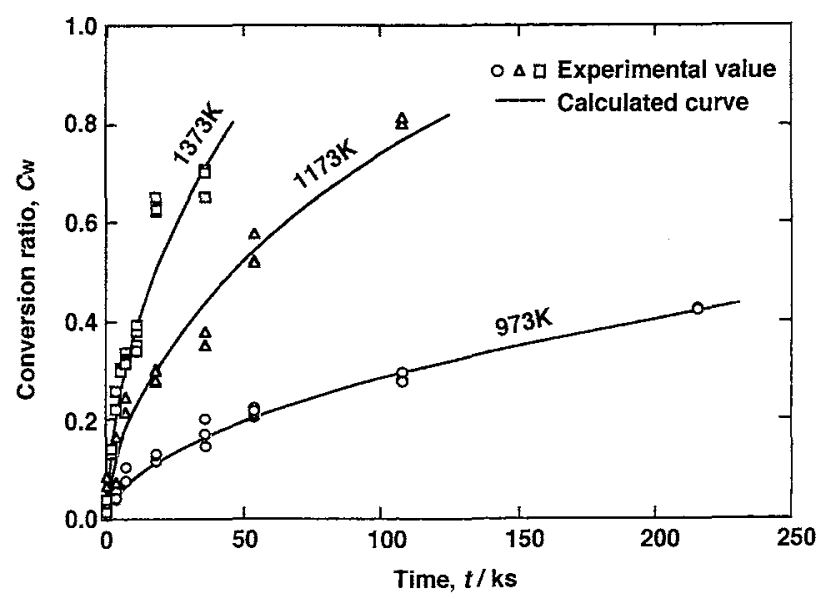

Fig. 7 The conversion ratio, $C_{\mathrm{w}}$, of the Ni wire dipped into molten Al. 


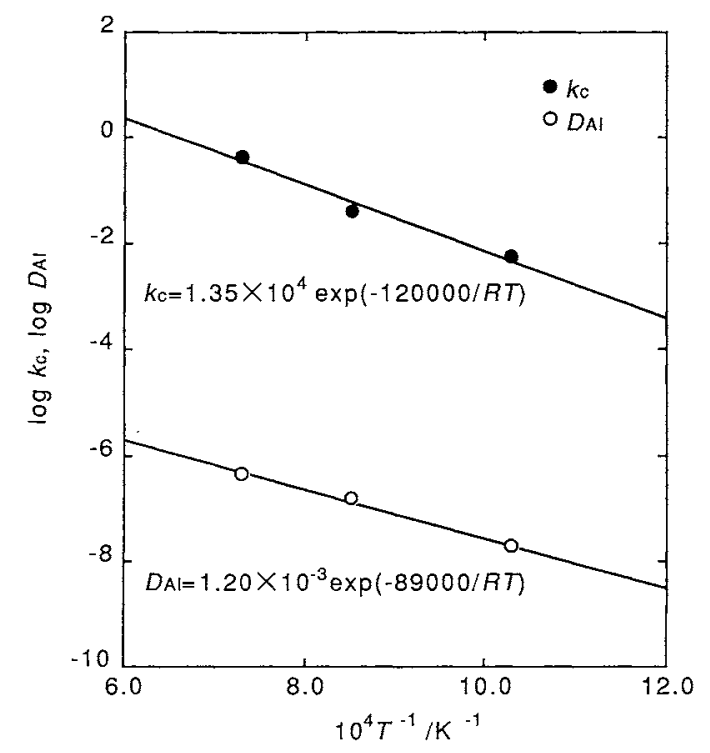

Fig. 8 Temperature dependence of the diffusion coefficient, $D_{\mathrm{Al}}$, and the reaction rate constant, $k_{\mathrm{c}}$.

係数 $D_{\mathrm{Al}}$ は, 温度の逆数に対してよい直線関俰を示している. したがってこれらのパラメータがアレニウスの関係を満足し ていることがわかる。この結果を最小自乗法を用いて整理した 結果, 拡散係数 $D_{\mathrm{A} 1}$ と反応速度定数 $k_{\mathrm{c}}$ についてそれぞれ以下 のような值を得ることができた。

$$
\begin{aligned}
& D_{\mathrm{A}} / \mathrm{mol} \cdot \mathrm{m}^{-1} \cdot \mathrm{s}^{-1}=1.20 \times 10^{-3} \cdot \exp (-89000 / R T) \\
& k_{\mathrm{c}} / \mathrm{mol} \cdot \mathrm{m}^{-2} \cdot \mathrm{s}^{-1}=1.35 \times 10^{4} \cdot \exp (-120000 / R T)
\end{aligned}
$$

Fig. 7 の実線に，式(18)，(19)を式(16)火代入し，転換率 $C_{\mathrm{w}}$ と時間 $t$ の関係を求めた結果を示す。图から明らかなよら にこれらの值による転換率の計算曲線は，実験值をよく再現 することがわかる。この結果を式(8)，(11)に代入し，各時間 毎の $r_{\mathrm{i}}, r_{0}$ を求めたところ Fig. 9 が得られた。すなおち, 浸漬 時間の増加につれ化合物層は成長し, 逆にNiワイヤ一内の未 反応のNiが減少する様子がシミュレートできる。

以上のように, 本系の反応速度パラメータが求まったので, 浸漬実験での反応機構の推定を試みた。式(15)によると，浸 漬実験に和ける反応の抵抗位，然燒合成(19) と同しく拉散の抵 抗 $R_{\mathrm{d}}:\left(\beta^{1 / 2} \gamma_{\mathrm{s}} / D_{\mathrm{A} 1} \cdot \ln \left(\beta^{1 / 2} / \alpha^{1 / 2}\right)\right)$ 之界面での反応の㧹抗 $R_{\mathrm{c}}$ : $\left(\beta^{1 / 2} / \alpha^{1 / 2} \cdot k_{c}\right)$ とから成り立っている. そして化合物の成長速 度は，これらの抵抗と反応の駆動力： $\left(2 \pi r_{\mathrm{s}} \beta^{1 / 2} l\left(a_{\mathrm{Al}, \mathrm{o}}-1 / K\right)\right)$ の比によって決定されている.ここで，拡散の抵抗 $R_{\mathrm{d}}$, 界面 での反応の抵抗 $R_{\mathrm{c}}, 2$ つ抵抗の内訳に着目すると， $R_{\mathrm{d}} \gg R_{\mathrm{c}}$

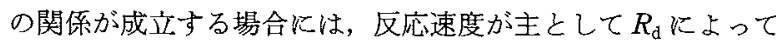
決まるので化合物の生成は拡散律速となる．逆化 $R_{\mathrm{d}} \ll R_{\mathrm{c}}$ の関 係が成立する場合には $R_{\mathrm{c}}$ によって反応速度が決まるので，化 合物生成は界面に猢る反応が律速となる。主なわち，これら 2 つの抵抗值を評価することで，反応機構の推定が可能とな る、そこで然焼合成の場合と同様，2つの抵抗の大小を比較す る方法で, 化合物の生成機構を推定した.

Fig. 10 にこれら2つの抵抗值を求めた結果を示す.この 図に見られるように，本浸漬実験の場合では应散の抵抗 $R_{\mathrm{d}}$ が 界面に括ける反応の抵抗 $R_{\mathrm{c}}$ を上回り，化合物の生成が拡散律 速のるとで進行することが明らかになった。

Fig. 11 に比較のため, $\mathrm{Ni}_{3} \mathrm{Al}$ の然㮱合成に和ける反応の抵 抗を示す ${ }^{(19)}$.この図とFig. 10 を比較すると，浸漬実験の埸 合では転換率の増大につれ，これらの抵抗值は増えている。 かしながら燃燒合成では抵抗值は減少し，全く逆の㑯向で多る ことがわかった．Fig. 8によると，拡散係数 $D_{\mathrm{A} 1}$ 括よび反応速 度定数 $k_{\mathrm{c}}$ は，温度によって变化する．これらは正の温度依存 性を持ち，高温では大きく低温では小さな値を示す。然焼合成 では試料温度の上昇により，これら抁散保数 $D_{\mathrm{A} 1}$, 反応速度定 数 $k_{\mathrm{c}}$ が大きくなることが原因で，反応の抵抗は減少するもの と考皇られる。一方，浸漬実験では，試料温度は漫漬中にほぼ 一定とみなせるため，搪散係数 $D_{\mathrm{Al}}$, 反応速度定数 $k_{\mathrm{c}}$ は一定 となる、炕もかからず，反応の抵抗が増加するのは，転換率 の増大に伴って化合物層が厚くなり，かつ $\mathrm{Ni}_{2} \mathrm{Al}_{3} / \mathrm{Ni}$ 界面の面 積が減少するためと思われる，ただし，これらの結果は仮定を 捈いたモデルから推察される結果であるため，詳細を議論する

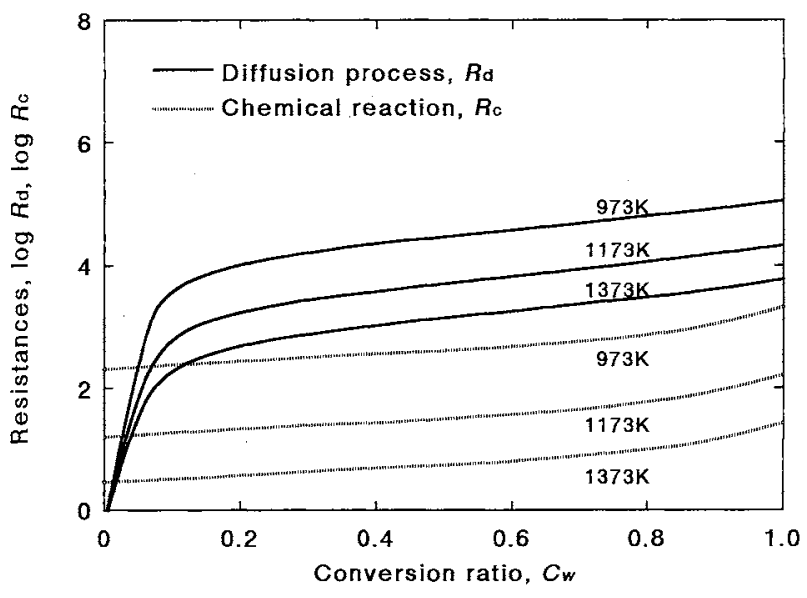

Fig. 10 Resistances of the diffusion process and the chemical reaction in the dipping experiment.

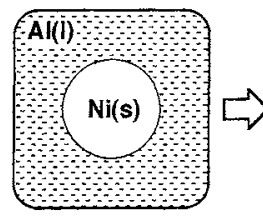

(a) $0 \mathrm{ks}$

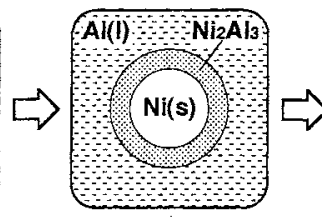

(b) $25 \mathrm{ks}$

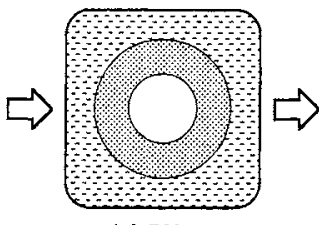

(c) $50 \mathrm{ks}$

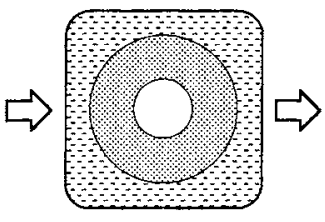

(d) $75 \mathrm{ks}$

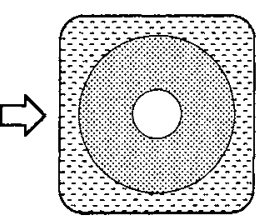

(e) $100 \mathrm{ks}$

Fig. 9 Schematic drawing of the growth of the intermetallic compound layer at $1173 \mathrm{~K}$. 


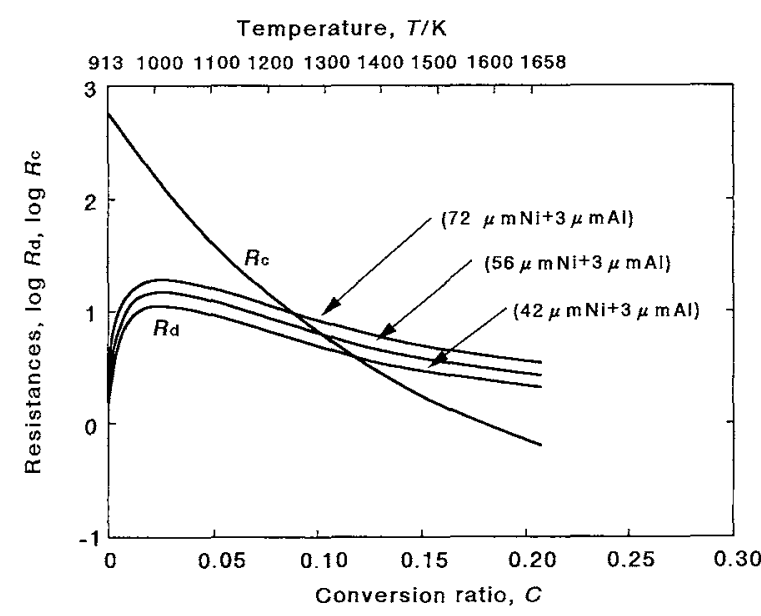

Fig. 11 The change of the resistances during combustion synthesis.

ためにはより詳しい検討が必要であると考えられる。

\section{N. 総 括}

本研究では，溶融 $\mathrm{Al}$ 中にNi甲イヤーを浸漬し，金属間 化合物の成長速度を湘定した。 そして，この結果に基づいて $\mathrm{Ni}_{3} \mathrm{Al}$ の燃焼合成に和㚈る反応速度パラメータを推定した。

（1）浸漬後の Ni ワイヤーKは，同心円状火金属間化合物層 が形成され，この化合物層の生成量は浸漬時間, 浸漬温度の増 大伴って堌克ることが明らか《なった。

(2) $\mathrm{EDX}$ 分析の結果から，生成した化合物層は $\mathrm{Ni}_{2} \mathrm{Al}_{3}$ であ り，これは $\mathrm{Ni}_{3} \mathrm{Al}$ の燃焼合成の反応途中で形成される化合物と 同相であることがわかった。

（3）筒モデルを用いて本浸漬案験の結果を整理し，溶融 $\mathrm{Al}$-固体 Ni 間の反応速度パラメータを求めた結果，以下の值が 得られた。

$$
\begin{aligned}
& D_{\mathrm{A}} / \mathrm{mol} \cdot \mathrm{m}^{-1} \cdot \mathrm{s}^{-1}=1.20 \times 10^{-3} \cdot \exp (-89000 / R T) \\
& k_{c} / \mathrm{mol} \cdot \mathrm{m}^{-2} \cdot \mathrm{s}^{-1}=1.35 \times 10^{4} \cdot \exp (-120000 / R T)
\end{aligned}
$$

また，これらの值によって求垤転換率の計算曲線は実測値 をよく再現した。

（4）このパラタータを用いて，浸漬実験に辞ける反応の抵抗
を計算した結果，浸漬実験では転換率の増大につれて反応の抵 抗孞上昇することがわかった。この結果は，燃焼合成の埸合と 全く逆の傾向であるが，これは，然焼合成では反応の進行に伴 って試料温度が上昇するのに対し，浸漬実験では一定温度で反 忍が進行するためと推察される。

本研究を遂行するにあたり，試料の機器分析で神奈川大学工 学研究所, 阿部勇輝氏のご指導を頂いた。誌面を借りて厚く御 礼申し上げる。

\section{文献}

（1）燃焼合成研究会編：燃焼合成の化学, ティー・アイ・シ 亿 一, (1992)

（2）海江田義也, 太田口稳，小黒信高，尾家 正, 平山 尚志：日本金属学会会報， 30 (1991)，554.

(3) Z. A. Munir: Ceram. Bull., 67 (1988), 342

（4）小田原 修，海江田義也：塑性と加工，28(1987)，3.

（5）宮本欽生，上條栄治，小泉光惠：粉体拉上び粉末冶金, $34(1987), 101$.

(6) S. D. Dunmead, Z. A. Munir: J. Am. Ceram. Soc., 75 (1992), 175.

( 7 ) S. B. Margolis: Met. Trans., 23A (1992), 15.

(8) M. G. Lakshmikantha, A. Bhattacharya and J. A. Sekhar: Met. Trans., 23A (1992), 23.

(9) 牧野 敦: New Ceramics, 4, No. 7 (1991), 79.

(10) A. G. Merzhanov: Archivum Combustions, 1(1981), 23

(11) A. G. Merzhanov: Congress CHISA Prague, (1975), 1.

(12) J. Wong, E. M. Larson, J. B. Holt, P. A. Waide, B. Rupp and R. Frahm: Science, 249 (1990), 1406.

（13）西村 睦，天野宗幸，海江田義也：日本金属学会誌， 54(1990), 603.

（14）鈴木良和，下川勝義，鵜沼英朗，植田芳信：粉体执よび 粉末治金, 37(1990)，433.

(15) L. L. Wang, Z. A. Munir and J. B. Holt: Met. Trans., $21 \mathrm{~B}(1990), 567$.

(16) A. Bose, B. H. Rabin, R. M. German: Powder Metall. Int., 20 (1988), 25.

(17) K. A. Philpot, Z. A. Munir and J. B. Holt: J. Mater. Sci., 22 (1987), 159.

(18) M. Igharo and J. V. Wood: Powder Metall., 28(1985), 131.

（19）日比野 敦：日本金属学会誌，56(1992)，1435.

(20) I. Barin: Thermochemical data of pure substances, VCH Publishers, Weinheim, (1989).

(21) P. D. Desai: J. Chem. Ref. Data, 16(1987), 109.

(22) T. B. Massalski, et. al. (Ed.): Binally Alloy Phase Diagrams, ASM, Ohio, (1986)

（23）橋本健治著: 反応工学，培風館，(1979), 222 .

(24) S. C. Schaefer and N. A. Gokcen: High. Temp. Sci., $11(1979), 31$ 